JOTE Volume 2 Nomor 1 Tahun 2020 Halaman 224-230 JOURNAL ON TEACHER EDUCATION Research \& Learning in Faculty of Education

\title{
Kemampuan Motorik Halus Melalui Kegiatan Kolase Dengan Bahan Loose Part Pada Anak Usia 4-6 Tahun di Bangkinang Kota
}

\author{
Nurfadilah ${ }^{1}$, Nurmalina ${ }^{2}$, Rizki Amalia ${ }^{3}$ \\ SI PG-PAUD, Fakultas IImu Pendidikan, Universitas Pahlawan Tuanku Tambusai \\ dilanurbkn80@gmail.com
}

\begin{abstract}
Abstrak
Penilitian ini bertujuan untuk meningkatkan kemampuan motorik halus anak melalui kegiatan kolase dengan bahan Loose part pada anak usia 4-6 Tahun di Bangkinang Kabupaten kampar. Penelitian ini menggunakan metode deskriptif analitis, yaitu metode yang bersifat memaparkan sejelas jelasnya tentang objek yang diteliti, serta menggambarkan secara keseluruhan, sistematis dan akurat. Penelitian ini dilakukan dua kali pertemuan. Penelitian ini adalah penelitian kualitatif, yaitu penelitian yang bermaksud untuk memahami fenomena tentang apa yang dialami oleh subjek penelitian, misalnya prilaku, presepsi, motivasi , tindakan dan lain-lain, secara holistik dan dengan cara deksripsi dalam bentuk kata-kata dan bahasa pada suatu konteks khusus yang alamiah dan dengan memanfaatkan berbagai metode alamiah. Hasil penelitian menunjukkan bahwa terdapat peningkatan kemampuan motorik halus anak dengan persentase kenaikan $22 \%$, hal ini dapat di lihat dari sebelum penelitian diperoleh nilai ratarata $60 \%$ namun setelah dilakukan penelitian meningkat menjadi $82 \%$.
\end{abstract}

Kata kunci: Kemampuan Motorik Halus, Permainan Kolase, Taman KanakKanak

\begin{abstract}
This study aims to improve children's fine motor skills through collage activities with loose part materials for children aged 4-6 years in Bangkinang, Kampar Regency. This research uses descriptive analytical method, which is a method that describes clearly the object under study, and describes as a whole, systematically and accurately. This research was conducted in two meetings. This research is qualitative research, which is research that intends to understand the phenomena experienced by research subjects, such as behavior, perceptions, motivation, actions, etc., holistically and by description in the form of words and language in a context. special nature and by making use of various natural methods. The results showed that there was an increase in the child's fine motor skills with a percentage increase of $22 \%$, this can be seen from before the study obtained an average value of $60 \%$ but after the research it increased to $82 \%$.
\end{abstract}

Keywords: Fine Motor Skills, Collage Games, Kindergarten 


\section{PENDAHULUAN}

Taman Kanak-Kanak merupakan salah satu bentuk Pendidikan Anak Usia Dini yang ada dijalur pendidikan sekolah. Sesuai dengan Undang-Undang Pendidikan Republik Indonesia No. 20 Tahun 2003 tentang Sistem Pendidikan Nasional Pasal 1 ayat 14 menyatakan bahwa Pendidikan Anak Usia Dini adalah suatu upaya pembinaan yang ditujukan kepada anak sejak lahir sampai dengan usia enam tahun yang dilakukan melalui pemberian rangsangan pendidikan untuk membantu pertumbuhan dan perkembangan jasmani dan rohani agar anak memiliki kesiapan dalam memasuki pendidikan lebih lanjut (Depdiknas,2003 dalam Siti, 2012:1.3).

Menurut Yuliani (2011:6) Pendidikan Anak Usia Dini merupakan salah satu bentuk penyelenggaraan pendidikan yang menitikberatkan pada peletakan dasar ke arah pertumbuhan dan perkembangan fisik (koordinasi motorik halus dan kasar), kecerdasan (daya pikir, daya cipta, kecerdasan emosi, dan kecerdasan spiritual), sosio-emosional (sikap perilaku dan agama), bahasa, dan komunikasi,sesuai dengan keunikan dan tahap-tahap perkembangan yang dilalui oleh anak usia dini.

Kemampuan motorik anak terbagi menjadi dua bagian, yaitu gerakan motorik kasar dan gerakan motorik halus. Pertama gerakan motorik kasar adalah kemampuan yang membutuhkan koordinasi sebagian besar bagian tubuh anak. Oleh karena itu, biasanya memerlukan tenaga karena dilakukan oleh otot-otot yang besar. Kemampuan motorik kasar seperti berjalan, berlari, melompat, naik turun tangga. Kedua gerakan motorik halus adalah gerakan hanya melibatkan bagian-bagian tubuh tertentu saja dan dilakukan oleh otot-otot kecil, seperti ketrampilan menggunakan jari-jemari tangan dan gerakan pergelangan tangan yang tepat (Bambang 2009:113-114)

Kemampuan motorik halus seperti dapat menyikat giginya, menyisir, membuka dan menutup retsleting, memakai sepatu sendiri, mengancingkan pakaian, serta makan sendiri menggunakan sendok dan garpu. Kemampuan motorik halus perlu dikembangkan di PAUD untuk melatih kekuatan tangan dan melatih koordinasi otot tangan dan mata. Apabila perkembangan motorik halus anak jelek, anak akan mengalami kesulitan untuk mengendalikan tangantangannya. Hal inilah yang menyebabkan ada anak yang jika memegang sesuatu mudah untuk jatuh karena tangannya kaku dan tidak luwes. 
Berdasarkan pengamatan terhadap anak usia 4-6 tahun di bangkinang didapatkan hasil bahwa kemampuan motorik halus anak masih rendah. Terbukti saat diberi kegiatan yang berkaitan dengan motorik halus, anak sering meminta bantuan guru untuk menyelesaikannya. Bila anak mengerjakan sendiri, hasil karya anak kurang baik. Ini terlihat dari hasil karya anak pada saat mengerjakan kegiatan tersebut. Selama ini guru lebih sering mengembangkan motorik halus anak dalam hal mewarnai, menggambar, melipat dan menulis. Kegiatan motorik halus lain seperti kolase jarang diberikan pada anak. Jika guru memberikan kegiatan kolase metode dan strategi guru belum bervariasi dalam proses pembelajaran serta media yang digunakan kurang menarik sehingga anak mudah merasa bosan.

Motorik halus merupakan suatu aspek perkembangan yang melibatkan pengorganisaian penggunaan sekelompok otot kecil seperti jari jemari dan tangan yang sering membutuhkan kecermatan dan koordinasi mata dengan tangan, keterampilan ini mencakup pemamfaatan dengan alat-alat untuk bekerja dan objek yang kecil atau pengontrolan terhadap mesin misalnya mengetik,menjahit dan lain-lain (Sumantri 2005: 143).Pemberian stimulasi motorik halus pada anak bertujuan untuk mematangkan otot-otot kecil pada tangan anak untuk persiapan menulis ketika masuk jenjang selanjutnya. Melalui kegiatan menyenangkan yang dapat mematangkan kemampuan otot-otot kecil anak diharapkan tidak tercipta keterpaksaan sehingga anak dapat berkresasi menggunakan jari- jemari tangannya untuk latihan awal dalam kemampuan menulis.

Kolase berasal dari kata "coller"yang artinya merekat. Selanjutnya kolase dipahami sebagai suatu teknik menempel berbagai macam materi, selain cat, seperti kertas, kain, plastik, kaca, logam dan lainnya. Sebagian dikombinasikan dengan cat (minyak) atau teknik yang lainnya. Kolase dapat rekat dengan berbagai jenis permukaan, seperti kayu, plastik, kertas, kaca dan sebagainya untuk dimanfaatkan atau difungsikan sebagai benda funsional atau karya seni (Susanto 2012:63)

Kolase memiliki unsur-unsur seni rupa lain, yaitu unsur seni lukis dari bentuk dua dimensi yang datar dan menggambarkan suatu bentuk tetapi diwakili oleh benda yang bermacam-macam sebagi pengganti garis,warna dan bidangnya.Kegiatan kolase sangat disukai oleh anak-anak terlebih menimbulkan kesan tiga dimensi. Permainan kolase merupakan salah satu permainan yang banyak melibatkan penggunaan motorik halus dalam kegiatanya. Sehingga 
harapanya melalui bermain kolase kemampuan motorik halus anak mampu berkembangn secara optimal.

Loose Parts adalah bahan yang dapat dipindahkan, dibawa, digabungkan, dirancang ulang, dipisahkan dan disatukan kembali dengan berbagai cara. Loose Parts menciptakan kemungkinan kreasi tanpa batas dalam aktifitas pembelajaran dan mengundang kreativitas anak. Menggunakan Loose Parts dalam pembelajaran anak merupakan media bahan ajar yang kegunaannya dalam pembelajaran anak tidak pernah ada habisnya. Bahan ajar loose part dapat digunakan sebagai alat untuk mengeksplorasi berbagai aspek: Pemecahan masalah, kreativitas, konsentrasi , motorik halus, motorik kasar, sains (Sience), pengembangan bahasa (Literasi), seni (Art), logika berpikir matematika (Math), teknik (Enginering), teknologi (Technology).

Berdasarkan pengamatan terhadap anak usia 4-6 tahun di bangkinang didapatkan hasil bahwa kemampuan motorik halus anak adalah sebagai berikut:

Tabel 1.1

Hasil Pengamatan Sebelum Penelitian

\begin{tabular}{|r|r|c|}
\hline No & Kategori & Frekuensi \\
\hline $\mathbf{1}$ & Berkembang Sangat Baik & 1 \\
\hline $\mathbf{2}$ & Berkembang Sesuai Harapan & 3 \\
\hline $\mathbf{3}$ & Mulai Berkembang & 6 \\
\hline 4 & Belum Berkembang & 5 \\
\hline
\end{tabular}

Sumber : Hasil pengamatan bulan Maret 2020 di bangkinang kota Kab.Kampar

\section{METODE}

Penelitian ini menggunakan metode deskriptif analitis, yaitu metode yang bersifat memaparkan sejelas jelasnya tentang objek yang diteliti, serta menggambarkan secara keseluruhan, sistematis dan akurat. Oleh sebab itu data yang dihasilkan atau yang dicatat adalah data yang sifatnya potret seperti apa adanya. Hal ini sesuai dengan pendapat Rama (2006:5) yang menyatakan bahwa metode deskriptif analitis dilakukan dengan cara mendeskripsikan faktafakta yang kemudian disusul dengan analisis. Analisis yang dilakukan menggunakan landasan teori yang dipakai kemudian dianalisisi dan di interpretasikan sesuai dengan kajian teori sehingga hasil penelitian nantinya 
dapat menguraikan permasalahan yang diteliti secara objektivitas, sistematis berdsarakan teori- teori yang penulis pergunakan adapun

Penelitian ini adalah penelitian kualitatif, yaitu penelitian yang bermaksud untuk memahami fenomena tentang apa yang dialami oleh subjek penelitian, misalnya prilaku, presepsi, motivasi , tindakan dan lain-lain, secara holistik dan dengan cara deksripsi dengan memanfaatkan kata-kata dan bahasa, pada suatu konteks khusus yang alamiah dan dengan memanfaatkan berbagai metode alamiah (Moleong 2010:6). Indikator keberhasilan dalam penelitian ini adanya peningkatan kemampuan motorik halus anak.

\section{PEMBAHASAN}

Data hasil penelitian tindakan yang dilakukan dari kegiatan penelitian dijelaskan pada table di bawah ini:

Tabel 1.2

Perbandingan Hasil Sebelum Kegiatan Dan Setelah Kegiatan Kolase

\begin{tabular}{|l|c|c|l|c|c|}
\hline \multicolumn{3}{|c|}{ Sebelum Kegiatan } & \multicolumn{3}{c|}{ Setelah Kegiatan } \\
\hline \multicolumn{1}{|c|}{ Kriteria } & Jumlah & Persentas & Kriteria & Jumlah & Persentas \\
\hline BSB & 1 & $6.6 \%$ & BSB & 12 & $80 \%$ \\
\hline BSH & 3 & $20 \%$ & BSH & 3 & $20 \%$ \\
\hline MB & 6 & $40 \%$ & MB & 0 & $0 \%$ \\
\hline BB & 5 & 3.33 & BB & - & - \\
\hline
\end{tabular}

Berdasarkan tabel 1.2 dapat dijelaskan bahwa keterampilan motorik halus pada saat sebelum kegiatan kolase, anak yang berada pada kriteria berekembang sangat baik ada 1 anak dari 15 anak atau 6.6\%, pada kriteria berkembang sesuai harapan ada 3 anak dari 15 anak atau 20\%, pada kriteria mulai berkembang ada 6 anak dari 15 anak atau 40\% dan pada kriteria belum berkembang ada 5 dari 15 anak atau 33.3\% dan di peroleh rata-rata 54\%. Sedangkan keterampilan motorik halus setelah penelitian, anak yang berada pada kriteria berekmbang sangat baik ada 12 anak dari 15 anak atau $80 \%$, pada kriteria berkembang sesuai harapan ada 3 anak dari 15 anak atau 20\%, pada kriteria mulai berkembang 0 anak dari 15 anak atau $0 \%$ dan pada kriteria belum berkembang ada 0 dari 15 anak atau $0 \%$ dan diperoleh rata-rata sebesar $82 \%$. Berdasarkan hasil penelitian sesuai instrumen yang telah ditentukan, maka dapat diketahui dalam pelaksanaan yang dilakukan, saat kegiatan kolase menggunakan bahan bekas menunjukkan bahwa keterampilan motorik halus anak meningkat. 


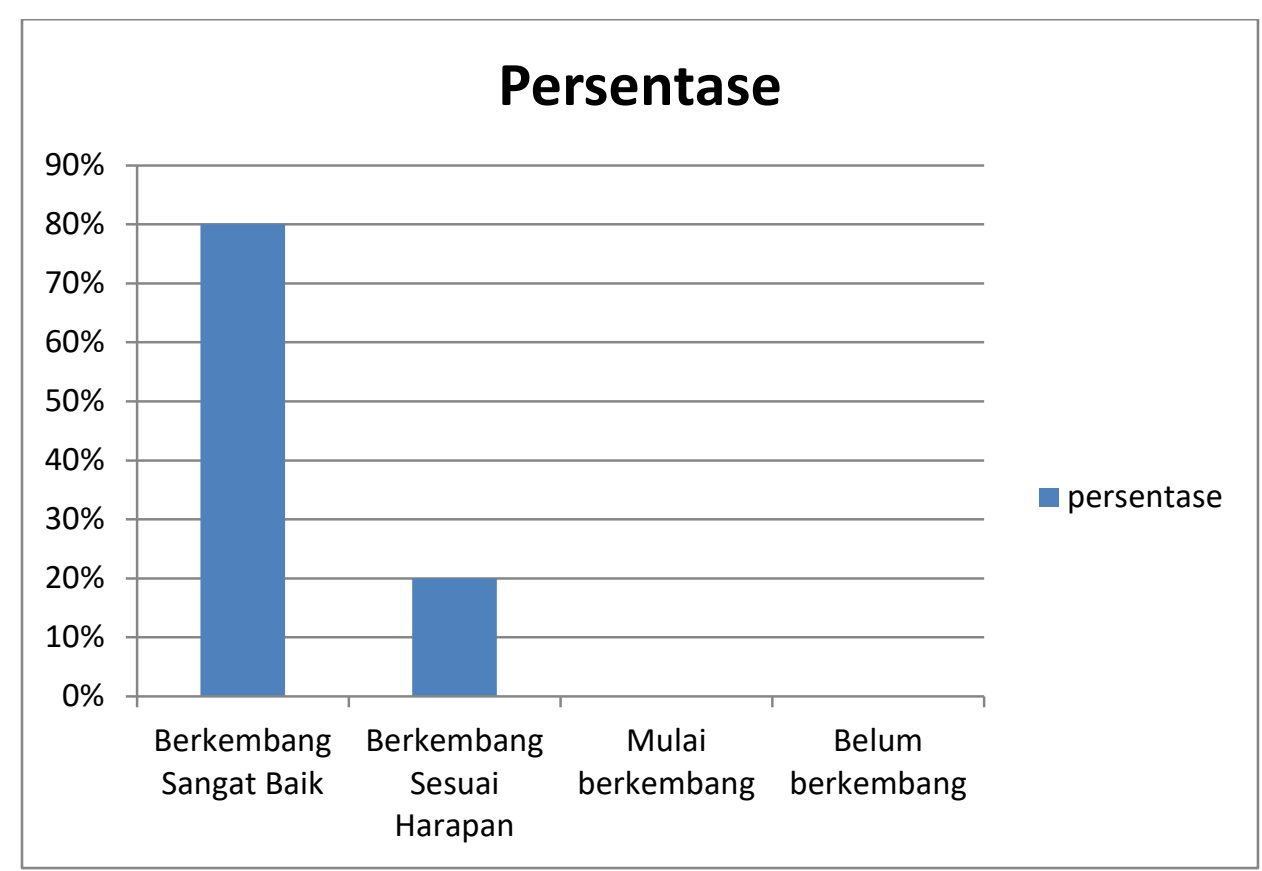

Gambar 4.2 Grafik Data Kumulatif Setelah Kegiatan Kolase

\section{KESIMPULAN}

Berdasarkan hasil analisis data dan pengujian dalam pembahasan, maka dapat diambil kesimpulan terdapat peningkatan kemampuan motorik halus anak usia 4-6 tahun di Bangkinang Kota menggunakan media bahan loose part. Peningkatan perkembangan motorik halus anak ini dipengaruhi penggunaan bahan loose part yang dimana salah satu media yang sangat baik dalam kegiatan pembelajaran untuk menstimulasi potensi anak yang mana media tersebut bisa didapatkan dilingkungan sekitar.

Untuk meningkatkan proses belajar mengajar dimasa mendatang maka penulis memberikan saran untuk meningkatkan minat belajar mengajar kepada anak usia dini, hendaknya seorang pendidik khususnya dalam mengembangkan motorik halus anak juga penting untuk memanfaatkan media yang ada di lingkungan sekitar seperti media bahan loose part, bahan alam, yang dimana bahan bahan yang digunakan tidak terkesan membosankan melainkan bervariasi dalam kegiatan pembelajaran

\section{DAFTAR PUSTAKA}

Bambang, Sujino. 2008. Metode Pengembangan Fisik. Jakarta: Universitas Terbuka.

Beal, D.J \& Delpachtra, S. B. (2003). Financial Literacy Among Australian University Stu- dents. Economic Papers, 22(1), 65-78.

Budiono, M.A. 2005. Kamus Besar Bahasa Indonesia. Jakarta: Depdiknas. 
Departemen Pendidikan Nasional. 2007. Pedoman Pembelajaran Bidang Pengembangan Fisik Motorik di Taman Kanak-Kanak. Dirjen Manajemen Pendidikan Dasar dan Menengah. Jakarta

Depdiknas. 2003. Undang-undang RI No.20 tahun 2003. Tentang system Pendidikan nasional.

Endraswara, Suwardi. 2011. Metode Pembelajaran Drama : Apresiasi, Ekspresi, dan Pengkajian. Yogyakarta: KAPS.

Hildayani, Rini. 2006. Psikologi Perkembangan Anak. Univesitas Terbuka.

Kamaril, Cut dkk. 2003. Pendidikan Seni Rupa dan Kerajinan Tangan. Jakarta: Universitas Terbuka.

Kasim, Saleh. 1981. Kerajinan Tangan. Jakarta: Dipdiknas.

Kurniawati. 2011. Penerapan Pembelajaran teknik kolase untuk meningkatkan kemampuan motorik halus pada kelompok B di TK SBI. Skripsi. Fakultas IImu Pendidikan. Universitas Negeri Malang: Malang

Moleong, j, Lexy. 2006. Metodologi Penelitian Kualitatif. Bandung: PT. Remaja Rosdakarya.

Ningtyas. 2012. Meningkatkan Kemampuan Motorik Halus Melalui Kolase berbahan alam Pada Kelompok B di TK Muslimat NU Khadiyah Nganjuk. Skripsi. Sekolah Tinggi IImu Tarbiyah: Mojokerto 